\title{
Lumen
}

Selected Proceedings from the Canadian Society for Eighteenth-Century Studies

\section{"Druid Rocks": Restoration, Originality, Nature and Authority in John Dryden, Titia Brongersma and William Blake's Visions of Megalithic Monuments}

\section{Eric Miller}

Volume 36, 2017

URI : https://id.erudit.org/iderudit/1037859ar

DOI : https://doi.org/10.7202/1037859ar

Aller au sommaire du numéro

Éditeur(s)

Canadian Society for Eighteenth-Century Studies / Société canadienne d'étude du dix-huitième siècle

ISSN

1209-3696 (imprimé)

1927-8284 (numérique)

Découvrir la revue

Citer cet article

Miller, E. (2017). "Druid Rocks": Restoration, Originality, Nature and Authority in John Dryden, Titia Brongersma and William Blake's Visions of Megalithic Monuments. Lumen, 36, 143-159. https://doi.org/10.7202/1037859ar 


\title{
"Druid Rocks": Restoration, Originality, Nature and Authority in John Dryden, Titia Brongersma and William Blake's Visions of Megalithic Monuments
}

\author{
ERIC MiLler \\ University of Victoria
}

According to John Hughes in his Boscobel Tracts, Charles Stuart spent Wednesday the seventh of October, 1651 , reckoning and re-reckoning the stones of Stonehenge, to beguile the time till he could return to his hostess Amphillis Hyde and her safe house, Heale. ${ }^{1}$ The King was fugitive from the rout at the Battle of Worcester. His companion Colonel Phelips claims that Charles's extemporary pleasure was to refute a "fabulous tale," namely, that the stones at Stonehenge could not be summed "alike twice together," but that rather, abiding under enchantment, they must perpetually elude human census. ${ }^{2}$ Similar demystifying empiricism inflects a 1663 poem on the topic by the royalist Dryden, though the stones really do seem to persist under the sway of innumerability. Charles counted what he saw. But (as recently as the summer of 2015) fully ninety more stones of no small size were detected on, or beneath, the Wiltshire Downs. So fable and fact part and meet at once. The past is - and remains - as difficult to prophesy as the future. Yet a megalith, that most assertive and simple of monuments

1. Alison Plowden reports that Mrs. Hyde recognized Charles at once and favoured him with dangerous generosity, with a double helping of larks at dinner. See Women All on Fire: The Women of the English Civil War (Stroud: Sutton, 2004), 173.

2. See J. Hughes, The Boscobel Tracts Relating to the Escape of Charles the Second After the Battle of Worcester and His Subsequent Adventures, $2^{\text {nd }}$ ed. (Edinburgh: William Blackwood \& Sons, 1857), 79, 175. 
and images, is predictably provocative, even when such massive commemoration itself is ruined and amnemonic.

For John Dryden, Stonehenge, with its crown-like arrangement of stones, marked the ceremonial venue of Danish coronations. For Titia Brongersma, the megalithic hunebed at Borger, in the Landscape of Groningen and Drenthe, Netherlands, comprised a temple to an entity of her own sex, the Goddess Nature, erected for (and to be restored by) panegyric to that divinity. For William Blake, Stonehenge amounted to both the relic and portent of the bloody and detestable practice and doctrine of vengeance, rather than Christian forgiveness of sins. What unites these poems is their will to displace not the megaliths, but an old version of the past. Patriotic Dryden prefers natural philosophy, advanced under Bacon, chartered by Charles II, to the controvertible authorities of Greece and Rome: fealty to a king thus still allows (even encourages) insubordination toward respectable pseudodoxia. Brongersma invokes an indigenous, yet universal female figure; in her allegiance to her native ground and its intellectual circle (centred at Groningen), she rejects or, better, sublimates to the glories of her homeland the legacy of Greece and Rome, while assuming the decorum of her congruity with a goddess. And Blake, despite the massacre at Welsh Anglesey (or Isle of Mona, in 61) and the legions' razing of the sacred groves there, aligns Romans with Druids, and dismisses both in favour of Judaeo-Christian revelation. Dryden, Brongersma and Blake therefore raise verses, if not books, like a ring of resonant, responsive stones, supernumerary to Stonehenge and to the hunebed, whetting by the keenness of their gaze the inscrutability of their topic, using the centrum phonicum supplied by these wonders to amplify their own voices. "As the Eye - Such the Object" says Blake. And if, as he asserts, "Every Eye Sees differently," then no object is available to a final 'reckoning.'

The special authority of these old structures precedes the literate revolution: they come from before books. Stonehenge and hunebed become Mosaic tablets that are also, conveniently, Lockean tabulae rasae. They remain, to use the latest parlance and the most current

3. See Blake's marginalia to Joshua Reynolds's Works in William Blake, Blake's Poetry and Designs, $2^{\text {nd }}$ ed., ed. by Mary Lynn Johnson and John E. Grant (New York: Norton, 2008), 464 . 
instance, equally illegible to, and inscribable by, hackers and their semblables, those hypocrite readers, the confabulating police (poets all, whether they will or no). Charles was not the last to combine the role of tourist with hunted refugee. Brongersma projected a resounding female voice in a place where the jealous atavism of paternal classics, perpetuated at Groningen, might not wholly smother it. William Blake directly associated the megaliths of Salisbury with his nation's wartime "Reign of Alarm," after the authorities charged him with high treason. ${ }^{4}$ The freedom of antiquity, a value and resource all three writers address, abides in its analphabetic taciturnity: Stonehenge and hunebed provide asylum for the interpretation and interpreters that they cannot satisfy. They erect a standing rebuke to surveillance's 'single vision.'

But the language of restoration, as confident as it is speculative, has insistently attached to them. In Dryden, nature restores the King who, though already recognized as such in January 1651, by the Covenanters at the stone of Scone, had yet to come into his crown. In Brongersma, a personified Nature is restored; and in Blake, Jerusalem would be restored - the imaginative body, rather than the merely vegetative one, in opposition to the state that can "Rob \& Plunder \& accumulate into one place, \& Translate \& Copy \& Buy \& Sell \& Criticise, but not Make." 5

\section{John Dryden and Stonehenge}

The first line of Dryden's “To my Honor'd Friend, Dr. Charleton On His Learned And Useful Works; And More Particularly This Of Stonehenge, By Him Restor'd To The True Founders" decries "tyranny." The poet's titular topics of restoration and foundation plainly carry the connotative weight not just of the ages, but of 1663 . The tyrant, perhaps surprisingly, is not Cromwell but a Greek philosopher - Aristotle. What has he to do with Stonehenge? A consideration of Dr. Charleton's context, lexical as well as theoretical, will help to elucidate this mystery.

4. I borrow the phrase "Reign of Alarm" from Kenneth R. Johnson, Unusual Suspects: Pitt's Reign of Alarm and the Lost Generation of the 179os (Oxford: OUP, 2013).

5. See "On Homer's Poetry" (Blake, 349). 
Inigo Jones, fancying that Vitruvian and Palladian geometry governed Stonehenge's configuration, alleged that he "restored" this ostensible temple to Coelus or the Sky, in a work that hypothesized a Roman origin to the monument, published posthumously in 1655 . Charles II's physician Walter Charleton, imagining that the Danes built Stonehenge as a king-making site shortly before their defeat by Alfred, restores it, as the erroneous Dryden declares, "to its true founders." John Aubrey, in unpublished work from the interregnum and afterward, credited Stonehenge to the British Druids: in 1740, William Stukeley, who adopted the sacerdotal identity of Chyndonax, "restor'd" the "temple" on Salisbury plain to the same sect - elaborating Aubrey's belief.' But what is 'restoration,' that arch-Carolinian, as well as archaeological, concept? A paradox, from the start: the OED tells us especially that it is to give back, to make return of anything previously taken away or lost; to make good loss or damage; to repair; to bring back to its original state; to retouch a thing, so as to bring it back to its original condition; to replace humankind in a state of grace; to replace a person in a former office, dignity or estate. But what is the original state? Which origin is to be preferred? The megalith is embodied but unrestored authority, nature and culture's equivocally. Aristotle is pertinent here precisely because he is impertinent: the consensus omnium keeps wrongly re-applying him. The Greeks are irrelevant.

Any authority would appear to be founded at one time, and to be sustained through subsequent time. In detecting the despotism of Aristotle over "free-born reason" (3), Dryden's poem rejects one kind of authority, and upholds another. ${ }^{8}$ It argues that nature, original in essence, must act as the arbiter, or guarantor of authority. In selfconsistency, nature or natural truth resists innovation, analogously as the Tories resisted political innovation; human beings in history may nevertheless come to new appreciations of this constant force.

6. Chorea Gigantum, or, The most famous antiquity of Great Britan, vulgarly called Stone-Heng, standing on Salisbury Plain, restored to the Danes (London: Henry Herringman, 1663).

7. See William Stukeley, Stonehenge A Temple Restor'd to the British Druids (London: W. Ennys and R. Manby, 1740). Aubrey visited Stonehenge as early as 1649; he returned in 1666.

8. I rely on the text of the poem appearing in John Dryden, John Dryden: The Major Works, ed. by Keith Walker (Oxford: OUP, 2003), 21-22. 
The classical auctor and naturalist Aristotle therefore figures as a fallible man promoted to tyrant when he offered a "torch" misunderstood as a "universal light” (1-4). In Dryden, trans-Atlantic Columbus proves such exemplary ancients deficient, in their failure to project a "New" World (9-20); this Renaissance commonplace had appeared in Thomas Browne's 1658 “Urn Burial," another early archaeological meditation: "That great antiquity America lay buried for thousands of years." Columbus may assume the glamour of a founder, but because America had immemorially preceded his advent, he is only a minority or exoteric restorer of that perpetual fact. Dryden substitutes Francis Bacon for Aristotle, paraphrasing by way of praise the "Proemium" to that thinker's 1620 Instauratio Magna or "Great Instauration." Bacon's focus was present and prospective, not past, authority. Despite his historical retrospection, Dryden chooses to emphasize the same tenses: "The world to Bacon does not only owe / Its present knowledge, but its future too" (23-24).

Dryden's verses pivot on the etymological and philosophical proximity of "restoration" to "instauration" - Bacon's now-archaic synonym for "foundation." So the poet extols William Harvey for discovering the circulation of blood (29-31). This "discovery" instates a critical foundation for the discipline of physiology, but amounts additionally to a kind of restoration (since blood has always circulated thus, and false authorities on the topic have had to give way). The case of William Gilbert, the Elizabethan investigator of magnetism, is similar (25-26). The useful needle almost always seeks "true" north, and would have done so had human beings happened upon that tendency any earlier (or later) than they did. This natural property of the mineral world (the world of Stonehenge) suggests the proleptic truing that might providentially have oriented Charles's reconnaissance of that supposed basilical icon, or place of coronation, at the very height of his disestablishment, setting the stage for his eucatastrophe the Restoration..$^{10}$

9. Thomas Browne, Religio Medici, Hydriotaphia and The Garden of Cyrus, ed. by R.H.A. Robbins (Oxford: Clarendon, 1972), 95. Dryden treats Columbus in lines 9-14, imputing aboriginal innocence to the indigenes of America.

10. I adopt the charming word "eucatastrophe" from J.R.R. Tolkien (The Monsters and the Critics and Other Essays [London: HarperCollins, 1990], 153; he uses it to describe Christ's career. 
As for Harvey's blood, it is the stuff of monarchical families, circulating through all their members - the king is dead, long live the king. Restored, Charles himself played the founder, in the process eroding the long rule of Aristotelian presupposition; in 1662, he chartered the Royal Society of London for Improving Natural Knowledge. Moreover, he both founds and restores the Monarchy (according to the protocols of the 1660 Convention Parliament). Blood, magnetism, and America supply, then, a series of parallel primals, "restored" to pristinity by those who institute (or affect to institute) some revelatory knowledge of them. Dr. Charleton's conjectural recovery of the original king-making function of Stonehenge fits this model, while flattering Charles's quantum of Danish blood. Like the rough magic of Stonehenge - and unlike Aristotle - the British constitution, unfinished yet enduring, participates in a condition of perpetual originality, in the natural constitution of things. It can, at need, be amended, too, like other kinds of natural knowledge. Dryden notes that, understood as a temple, Stonehenge offered sanctuary to Charles: now that he is King, it is revealed to have been a "throne" all along (57-58).

\section{Titia Brongersma and the hunebed}

The Dutch or, more precisely, Frisian writer Titia Brongersma, author of the pieces collected in the 1686 Swan of the Well, or Poems in Various Genres, and almost exact contemporary of Aphra Behn, is hardly known in North America. ${ }^{11}$ Just so, outside of the Netherlands and parts of Germany, the hunebedden do not receive a deep or frequent nod of recognition. These megalithic structures possess roofs, unlike Stonehenge; their height is less than that of the monument at Salisbury; but they rely analogously on the form of the trilithon for monumental integrity. Glacial erratics supply their stones, preponderantly granites greatly distinct from local geology. The hunebedden were

11. The Swan of the Well, or Poems in Various Genres is my translation of Brongersma's title De Bron-Swaan, of Mengeldigten (Groningen: Carel Pieman, 1686). The dates of Brongersma's birth and death are unknown: consensus guesses 1650 for the former, and must assume a year some time after 1686 for her decease. Johannes Adolph Rappardus's prefatory poem for Brongersma is not dissentient when it calls the poet the "Frisian Sappho." The painter Joannis Fedensma says "Even Sappho stands abashed / And regretfully concedes her place / Now that Titia looms up, now that Sappho is outshone." 
erected perhaps five millennia ago - age-mates of Stonehenge. Titia Brongersma visiting with a friend, Jan Laurens Lenting, at Borger, Drenthe, around Pentecost, 1685, probed the longest of extant hunebedden: and located, beneath that overarching structure, on the occasion of what was possibly the first formal excavation at the site, friable urns containing burnt remains. A contemporary print depicts Brongersma at the hunebed approached by male helpers in the garb of the period (breeches, jackets, hats with brims). One of these men offers her an object. She perches, seated barefoot on her own erratic boulder, turned almost fully away from the viewer, wearing a light-coloured wrap - the himation worn over the customary chiton, imagined appropriate to the reborn lyricist Sappho, one of Brongersma's honourifics in her circle, as it was for Aphra Behn in hers. ${ }^{12}$ Like Behn's, Brongersma's work, alternately intimate and courtly in intonation, innovatively adapts, as well as conforms to, masculinist traditions - erotic and otherwise..$^{13}$ Like Behn, she is a patriot, in this case a propagandist of the House of Orange $^{14}$; and like Behn, she compelled the support of both men and women in her sphere, notably (in the special case of the hunebed) the Groningen polymath Ludolph Smids (1649-1720). Here is her poem on the megalithic monument, in my translation. Note that it truly is Sapphic in character, inasmuch as it obeys the protocols of the priamel, a form made famous by the Greek writer's Fragment 16. A priamel canvasses a series of choices, the poet deciding to reject them all in favour of her last preference:

Praise of the Hunne-bed, or the prodigious, piled-up heap of boulders at Borger, in Drenthe

I stood like one to stone turned staring At the stacked rocks, boast of heroic Huns Apparently, who willed the building of a Monument to secure a footing on glory's

12. Brongersma's costume resembles, for example, some statuary representations of Hera's - though Brongersma probably never married.

13. For a fuller discussion of her sexual persona, see Lia van Gemert, "Hiding behind words: lesbianism in seventeenth-century Dutch poetry," Thamyris 2.1 (Spring 1993), 11-44. See also Annelies de Jeu, 't Spoor der dichteressen (Hilversum: Verloren, 2000).

14. She writes in praise of Hendrik Casimir II, Stadtholder of Friesland and Groningen (1664-96) and his consort Henriette Amalia of Anhalt-Dessau. He became the first hereditary Stadtholder of the region. 
Sheer gradient. No: this mass congeals a dream of

Resentful giants upreared, vying with godhood

Though they say Mulciber's thunderbolt split

It, flaring, into fragments. Or is it a pyramid

Dragged into place? Or a grave? For this gross,

Craggy cumulation encloses in

Its substrate carcasses, ancient sacrifice.

No. More likely it is Natura's marble

Temple where she desires that her divinity be

Honoured. She would hear at the verge of her nine-fold

Threshold nothing beyond a song of praise.

Let Thebes boast of walls tall enough to scrape

The sky, this rocky monster will outlast her,

No force though great can crack it all to bits.

Come nymphs, and come you rustics of Drenthe,

Make splendid with your praise this mineral palace

That would be piled with flowers. Render to Nature

What is elementally hers, and her tribute.

I offer in a hoarse and throaty voice a song

Of praise to extol this marvel of a cave and

Prepare the oaken crown to deck the great

Castle of boulders.

Brongersma musters and rejects hypotheses explanatory of the Dutch "Stonehenge." By writing a song of praise, she reactivates what she considers to be the primal purpose of the temple - to be a resonator for hymns to Nature. She thus does what she theorizes once was done: she delves into the literal as well as ideal foundation of the structure, and performs as its musical restorer. Song itself suffices for the medium of restoration. The song is exchangeable for the structure itself, since the structure was designed for the performance of the song or the singer, in behalf of the goddess Nature. Panegyric waits instinct in the architecture, a chamber contrived for the expression of the near-coincidence - a praising creature, and her praised creator.

Let us consider the accounts that Brongersma rejects. First comes any origin at the hand of the Huns (2-5). This specious aetiology derives its reason from a misreading of the word 'Hun.' The poet here assumes that these Huns must be a people. But - in Dutch already archaic - the term encompassed no historic human tribe, but rather the imaginary race of giants. That usage died out around 1590. Brongersma does, however, mention giants (Reusen) in their own right, only to disbar 
their contribution. ${ }^{15}$ The mythic English parallel is epitomized in Dr. Charleton's titular bow to an alternative name for Stonehenge, namely, Chorea Gigantum or "Dance of Giants," once orchestrated, according to fantasists, by the wizard Merlin. Mulciber being introduced (7), Brongersma mixes in a memory of Pelion piled on Ossa, the revolt of Titans against Olympus; she thus confects a culturally syncretic medley, characteristic of the period. Brongersma's citation of a pyramid (8) may recollect Horace's Ode 3.30, Exegi monumentum aere perennius, / regalique situ pyramidum altius ..., verses that assume poems will outlast the haughty edifices of worldly grandees. ${ }^{16}$ The evidence of urn burial, meanwhile, she found real: but Brongersma chooses to associate this fact with sacrifice - a making holy - rather than with exclusively mausolean intentions (9-11).

Brongersma's "nine-fold threshold" amounts, in my 2014 experience, to an inadequate reckoning of the hunebed's apertures. The number, however, relates to recurrent figurations in the poems of The Swan at the Well: it designates the number of Muses, taxonomized by the founder-bard Hesiod (14-15). Besides, fortified Thebes - which the hunebed is reckoned greater than, in a typical, almost Miltonic piece of late-Renaissance "outdoing" - possessed, by comparison, a mere paltry seven gates. Brongersma appears not only to extol her local antiquity over classical precedent, but also to assert the superior power of her natural music to that exercised by the legendary mage and musician Amphion, who by playing the harp manoeuvred the enormous blocks of the Theban city wall into place. Her panegyric surpasses this son of Zeus's, and (like a spell) it effects a restoration, in the moment when anyone reads her poem, of Great Creating Nature's incontestable sovereignty (16-18). The tribute offered to the female deity renders unto her what is already hers - flowers, and oak-leaves. The latter are associated by Aulus Gellius (author of Attic Nights) and by Boethius with the primordial state of humankind, when we all dined on acorns. As for Brongersma's curious characterization of her voice ("hoarse and throaty"), these epithets often, in antiquity, described the calls of

15. Johannes Picardt in 1660 engraved a print in which giants assemble a hunebed, carrying boulders on a litter and brandishing clubs.

16. "I have built a monument more enduring than bronze / And loftier than the pharaonical dilapidation of pyramids." Samuel Munkerus claims in his flattering verses to Brongersma that she out-sings "the Venusian swan" - that is to say, Horace. 
swans. Here is an instance from the anonymous Pervigilium Veneris, celebrating the spring-time night-watch of the love-goddess, possibly an artifact of the third century, sometimes assigned to Tiberianus: iam loquaces ore rauco stagna cygni perstrepunt - "now the garrulous swans bugle with a hoarse voice across the ponds." ${ }^{\prime 7}$ Brongersma often assimilates herself to this kind of bird, swimming in the canals of both Groningen and Drenthe, and in the visionary horse's well, Hippocrene - emulating the congeneric metamorphoses of Pindar and Horace before her. ${ }^{18}$ As Dryden disparaged the Hellene Aristotle and aligned a northern "nature" with human nature in the sponsorship of his polity and king, so Brongersma chooses to celebrate, despite her classical learning, the goddess Nature, a divinity as Dutch as she is universal. ${ }^{19}$ Dryden posits in the advancement of Baconian inquiry a continually refreshed encounter with origin and originality. Ludolph Smids saluted the twofold originality marking his friend Brongersma's excavation at Borger and her authoritative poetic testament: "so far as I know she is the first to dig beneath these stones. Truly a deed to be eternized by the art of poetry!"20

\section{William Blake and Stonehenge}

Julius Caesar's De Bello Gallico may furnish the ultimate origin for the belief that the Druids sacrificed human beings inside gigantic wicker baskets, or immense carceral effigies set aflame; Strabo speaks of such

17. See Anonymi, sed Antiquae tamen Poetae elegans et floridum Carmen de Vere communiter Pervigilium Veneris ..., ed. by And. Rivinus (Leipzig: Apud Joannem Presstum, 1644). I quote line 83 of Rivinus's edition. He remarks that the phrasing derives from Vergil: Dant sonitum rauci per stagna loquacia cygni, "The hoarse swans make noise in the uproarious sloughs" (35). The Pervigilium Veneris ends with a sorrowful confession of the speaker's imminent silence (Perdidi Musam tacendo, "I have lost the Muse by keeping quiet" [91]); Brongersma, contrarily, re-invokes what she conceives of as a lost source of inspiration, the Goddess Nature - giving voice to that restored divinity's long-overlooked praise.

18. Horace calls Pindar "the swan of Dirce" (Dircaeus cycnus); Dirce is a wellspring near Thebes, Amphion's town.

19. It may be asked, "Just what does Brongersma intend by her goddess "Natura'?" She means the numen of Friesland. At the same time, a neo-platonic ideal probably informs her conception, of the kind expressed in Boethius's Consolation of Philosophy: Natura potens holds the universe together by law and love.

20. See Lukas Koops, Het geheim van het grootste hunebed: Discussies over archeologie (Bedum: Profiel, 2008), 18. 
colossi of straw and wood, caging men destined for incineration; Aylett Sammes in England made a memorable etching in 1676, representing a colossus of this kind - visually a parody (or fulfillment) of Hobbes's Leviathan. William Blake certainly associated Stonehenge with Druids, following the mistaken John Aubrey and William Stukeley - Druids ensanguined by their human victims, whether burnt or disembowelled. ${ }^{21}$ Blake further connected those practices with the punitive state and status quo and their personal emissary the soldier John Scofield, who trespassed on his Felpham cottage yard, on 12 August, 1803, and denounced him for seditious utterances - Blake being acquitted of high treason in $1804 .{ }^{22}$ He sees Stonehenge as Natural Religion's aptest cultic architecture - model temple of an abhorrent doctrine, Deism: "The Building is Natural Religion \& its Altars Natural Morality / A building of eternal death" (Plate 66, 8-9). ${ }^{23}$ Here "nature" serves, then, neither as the standard of Baconian experience nor as an experimental proof of indigenous kingship, nor as a female principle allied to the Frisian muses, stronger than any sky-god, masculine bard, or merely civic power: "nature" instead rules the domain of mechanical causality, the enemy of the "Infinite": "The desire of Man being Infinite, the possession is Infinite and himself Infinite." ${ }^{4}$ For Blake, "Natural Religion," infatuated with belief in innate and inalienable human goodness, denies the necessity for the doctrine of forgiveness. Thus Stonehenge as well as its corollary in London, the "London Stone" (a limestone block reputed to be the miliarum from which the Romans reckoned all roads in Britannia) is the foundation, the institution, the

21. Aubrey Burl quotes one of John Aubrey's quainter proofs: "I thought of Aves Druidum when I saw the Stares [Starlings] breed in holes of the Stones of Stonehenge. The Welsh do call Stares Sturni Adar Y Drudwy i.e. Aves Druidum, 'birds of the druids,' because they could talk." See Burl, John Aubrey \& Stone Circles: Britain's First Archaeologist (Stroud: Amberley, 2009), 23. In 2014, I witnessed Jackdaws, not Starlings, investigating the hollows of the stones. Skylarks - Charles's dish - sang nearby.

22. Blake was also charged with assault and absolved of that charge, despite the palpable bias of the judge Charles Lennox, the third Duke of Richmond (1735-1806), who "made several unwarrantable (i.e. technically illegal) observations against Blake to the jury - a regular feature in the conduct of sedition and treason trials throughout the decade" (Johnson, 315).

23. I rely throughout my discussion of "Jerusalem: The Emanation of the Giant Albion" on the text of The Complete Poetry \& Prose of William Blake, ed. by David V. Erdman (New York: Anchor, 1988). Chapter 3 is prominently preoccupied with megaliths.

24. Proposition VII in "There is No Natural Religion" (1788). 
perpetual restoration, of capital punishment, whose local totem, for Blake, had been Tyburn.

Stonehenge is, above all, as Blake insists, a "Building." When he arrived in Felpham, before the intrusion of John Scofield, he celebrated the contrasting habitation in which he began to live and to work on the epic "Milton": "my cottage," he reported to John Flaxman in September 1800, is "a shadow of [celestial spirits"] houses." 25 If Stonehenge is perennially restored by the enemies of eternity, Blake's cottage is a counter-example of that revival: the poet reports seeing his own and his correspondent's "houses in Eternity." ${ }^{\text {"6 }}$ Like Dryden and Brongersma, the poet wishes to dismiss a narrative of the national past. Felpham may be "the sweetest country upon the face of the Earth," but that country ought to be disentangled from a foundation story that meshes and emphasizes Druid and Roman inextricably. Perhaps he had in mind Julius Caesar's friendship with Divitiacus the Eduan, Arch-Druid of Gaul, as a pattern of their philosophies' ultimate atrocious similarity; Caesar invaded England twice in the course of his Gallic campaign. The dragoon Scofield analogously invades. Although Blake resists the state, he resists equally the imputation of treason to the state. Trespass affronts him as much as his accuser's perjury. Thus, for all his visionary dissent, he conforms to William Blackstone's famous estimate of the case, in the fourth volume of his Commentaries on the Laws of England, Chapter 16: "the law of England has so particular and tender a regard to the immunity of a man's house, that it stiles it his castle, and will never suffer it to be violated with impunity." Kingship or, better, sovereignty, is the prerogative of the householder, whatever his opinions of George III. Blackstone characterizes this belief as a bedrock national trait - original to the constitution of the land. Ironically, in view of Blake's abhorrence for a Roman origin, Blackstone continues: the law agrees "herein with the sentiments of ancient Rome"; Cicero supplies the instance, relating the sacred maintenance of the domus's religious space to the rights of citizenship. ${ }^{27}$ To agree with sentiments, however, is not to allege an origin from them.

25. See Blake, ed. by Johnson and Grant, 474.

26. Ibid., 475.

27. See William Blackstone's Commentaries on the Laws of England, $4^{\text {th }}$ ed., vol.4, ch.16 (Oxford: Clarendon, 1770), 223. I would like to thank Dr. Monique W. Dull for compelling me to think about the origins of what we now call 'police powers.' 
One etymology of Stonehenge - Stan-hengen - translates the name as "Hanging Stones," gargantuan semblance of gallows. Capital punishment begins, for Blake, with the closing down of the senses and of imagination. In the world of "Jerusalem," therefore, the antithesis of Stonehenge is not so much, perhaps, his cottage, as it is "a Tent and Tabernacle of Mutual Forgiveness Male \& Female Clothings" (Plate $54,4)$. This phrase exalts a divine volatility: the tabernacle was the portable sanctuary of God. A tabernacle is a tent; "Male \& Female Clothings" align this tenting and tabernacling with the dress in which anyone may be clad. The human body divine is preferable to Druid rocks, and Roman milestones. "Man in the Resurrection changes his Sexual Garments at will” (Plate 61, 51): what we call experience and what we call gender are contingent matters. In his polemic against Natural Religion, Blake remarks that "God becomes as we are, that we may be as he is" 28 : here he may share some conviction with Brongersma, whose panegyric exemplifies and embodies as well as restores the audible goddess. ${ }^{29}$ Blake's Christian resurrection through the Poetic Genius is a recovery and restoration of origins, namely Eden.

With what measures does Blake link the Druids of his visionary Stonehenge? They mandate female chastity. They appoint Captains, officers whom their conscripts fear "more than the enemy." ${ }^{30}$ According to Blake, Stonehenge's Druids even slew the King of Canaan. Dryden promoted temporal kingship, and Brongersma lauded the worldly House of Orange; Blake is obliged by the figural repertoire of the Bible

28. The terminal assertion of "There is No Natural Religion." The use of the present tense implies, in the terms of my argument, the eternally coexistent moment of restoration and of origin (or originality).

29. But Blake's "Jerusalem" resists and abhors a relapse to a Baconian "Nature Mother of all" (Plate 30 [34], line 9), "denying Eternity / By the Atheistical Epicurean Philosophy” (Plate 67, lines 12-13). Refuting Vergil's Georgics, Blake derides those who "call the Rocks Parents of Men" (15). Thus Vergil: Deucalion vacuum lapides iactauit in orbem, / Unde homines nati, durum genus. See P. Vergilii Maronis Bucolica et Georgica, vol. 1, ed. by J. Mehler (Leiden: E.J. Brill, 1950), 62-63, "Deucalion cast onto the empty earth stones / Whence men arose, a hard race."

30. William Wordsworth's "Salisbury Plain" (begun in 1793) reads like a naturalistic rendition of some of Blake's preoccupations in "Jerusalem": militarism brings with it aggravated domestic and penal sequelae. In Wordsworth, Stonehenge prompts the (factitious) vision of a "sacrificial altar fed / With living men" (184-85). But Wordsworth ends his career by endorsing capital punishment, even when (in his own verse) the malefactor has already achieved perfect atonement. See William Wordsworth: The Major Works, ed. by Stephen Gill (Oxford: OUP, 2000). 
or "Great Code," like John Milton, to use monarchical imagery even when he would resist the constitution under which he lives. Blake tells us how the King of Canaan was murdered: "They pour cold water on his brain in front, to cause lids to grow over his eyes in veils of tears" (Plate 66, 30-31). The crowd of revengers, alienated from "Salvation," which is "in the Continual Forgiveness of Sins / In the Perpetual Mutual Sacrifice in Great Eternity" (Plate 61, 24), torturing the senses of that King, destroy their own: "their eye and ear shrunk" (Plate 66, 40). For Blake, all sacrifice must be reciprocal. The emphasis on sensory deprivation derives its origin from the actual words of the belligerent soldier John Scofield. He had threatened the poet and painter with nothing less than injury to that crucial birthright, his endowment of vision: "I desired him" (Blake recounted) "as politely as was possible, to go out of the Garden; he refused. I still persisted in desiring his departure; he then threatened to knock out my Eyes." 31

As obdurate as Druid rock itself is Blake's satire on the vindictive Scofield, whose adventitious name, spelled in various ways ("Skofeld" is one variant), appears to carry in it acoustically the very motive of mockery: 'Scoff.'32 Then does that remnant remain unforgiven? When your trespasser has been so improbably munificent as publicly to accuse you and indict you, you may forgive yourself for making him the cornerstone of your own monument - your counter-monument, complete with images of Stonehenge suspended weightlessly in the tabernacle of your verse. Authority in any case accrues from resistance to authority. Dryden satirizes the endlessly reiterated creed of Aristotle; Brongersma trumps as woman and Orangist the patriarchal lore of the Greeks, on the mastery of which her male patrons such as Smids prided themselves, and with which she herself was considerably conversant; Blake excoriates the fool, the probable hireling who violated his Beulah, his garden tabernacle, even his Eden - appealing not to George III but, by the inspiring fatality of Scriptural authority, to the

31. Quoted in Michael Davis's William Blake: A New Kind of Man (Berkeley: University of California, 1977), 106. Johnson in his Unusual Suspects notes, "In later years, Blake claimed that some 'high' person or persons 'sent the soldier to entrap him,' purposely to ruin him, at Felpham, that it was not just Scofield and Cox [Scofield's dubious accomplice] mugging up their charges against him .... I find the possibility not at all unlikely, and certainly not paranoid" (321-22).

32. The phrase "Druid rocks," which I adopt in my title, is to be found at Plate $54,26$. 
Hebrew King of Kings. In Felpham, Blake also endorsed a model of more mundane monarchy, alongside apocalyptic spiritualism. As Steven Goldsmith observes, "Throughout his life, the single-occupant [dwelling] would return as a figure of autonomy: it signified the selfpossession of 'the Mind in which every man is King \& Priest in his own house." 33 Charles Stuart once sought a safe house on Salisbury Plain; Blake's need was not, in this regard, so different from a royal fugitive's.

\section{Conclusion}

It is not easy to wield a megalith like a skipping stone. The stone skips from mind to mind, over time. The guide to the hunebed available at Borger, in Drenthe, Netherlands, asserts that opgraven is vernietigen, "to dig up is to destroy." 34 On the basis of this formula, Dutch law now prohibits excavation like Titia Brongersma's. Creation and destruction are too alike; Smids reports of the urns that Brongersma extracted at Borger: "So soon as they were withdrawn from the stony heap, they crumbled into bits." 35 We are condemned to originality more than to restoration, because our strivings in the latter field ruin even ruins. What prevents us therefore from overthrowing these old monuments and reducing them to dust, as factions have always and have recently done? Brongersma wrote well of Zenobia, queen of Palmyra. ${ }^{36}$

Responding to Ludolph Smids's playful instigation, Brongersma explains, in an address to one of her hunebed artifacts, the rationale for her researches. Imagination is the origin of the authority that she asserts. Brongersma substitutes for the assumed grief of ancient strangers her story of intellectual love. Such love is sufficiently restorative, although the house of the dead, fine and private as it is, enjoys inviolable immunity from ultimate appropriation - in this resembling Blackstone's habitation and Blake's visionary home:

33. See Steven Goldsmith's Blake's Agitation: Criticism and the Emotions (Baltimore: Johns Hopkins, 2013), 106-7.

34. A whole chapter of Koops bears this assertion as a title. The Netherlands passed legislation protecting ancient monuments such as hunebedden as early as 1734; in England, Stukeley regretted the prevalence of casual vandalism in 1740.

35. Koops, 18. My translation.

36. In Zenobia, Brongersma characteristically celebrates a female monarch. 
I felt for you, salt tears thickly coursing, Soaking through your opening to the bottom

Where remains lay packed in you, while I kneeled

In front of you, the crumbly stuff sifting

From the burst seal burial long sanctified.

I looked at you, oppressed, and immersed myself

In ancient woe. There you appeared: lifeless,

Condemned to death in the grimy grave of such

An uncanny monument, all broken potsherds

(A sight to distress my eyes) crushed under

Hard stones. I moved you into sunlight's warmth

And walked bravely with your relics, away.

I dispose your epochal, occult mortality

Before the gaze of all, with a lover's care. ${ }^{37}$

37. Smids's own poem, "On the Swabian urn dug up in pieces beneath the socalled Hunebed at Borger (To Titia Brongersma)," is worth quoting. It appears in Anon., Drenthe in vlugtige en losse omtrekken geschetst door drie Podagristen, Eerste Deel (Koevorden: D.H. van der Scheer, 1843), 151-52:

I rested on a bosom before I was buried

Surpassing the whiteness of milk, of lilies.

This hard earthen urn was kissed by lips,

Lips whose affection none can praise enough.

Wet with hot tears, O Titia, I witnessed

A youthful woman of the north stuffing my belly

With mortal remains for she sat on the paving

Of stones before the funeral altar, and sifted

The ashes of her darling out of burnt raiment.

She choked in her woe, her sorrow: in embracing

That grey urn she looked as if she would die.

You climbing into the unguarded structure, curious,

Dug me up, learnedly parsed my fragments,

A cruel sagacity, for I have not seen day

Since the Saxon died, the Dane and wild

Swabian. O lady, what would you do now

With these potsherds? Lay them down again, cover

The relics and remains and close me up again

As what I was and I am, a faithful lover.

The nameless quoter of this old verse remarks, Merk hier een Dichtkonstige Vryheid in het onderstellen, dat in deese busse de beenderen van een jongeling souden gelegen hebben, "Observe here the poetic licence that would assume the presence in the urn of the remains of a young man" (152). The commentator implies that Smids patronizes Brongersma. If so, Brongersma's riposte deflects Smids's emphasis on sentiment onto the plane of intellectual curiosity - curation as caring. 
In 1693, after the Glorious Revolution and the loss of his laureateship, Dryden published "The Fable of Acis, Polyphemus, and Galatea, from the Thirteenth Book of Ovid's Metamorphoses." As in Brongersma's poem, love is a topic. Jealous when he discovers the Nereid Galatea embracing Acis, the cyclops Polyphemus hurls a death-dealing stone - a murderous megalith, to crush her enviable lover. But this projectile, intended to extinguish the monster's rival forever, instead precipitates Acis's apotheosis. The man becomes a divinity, a Blakean god, "his stature taller than before, / His bulk augmented, and his beauty more" $(228-29) \cdot{ }^{38}$ Brongersma turns traces of desolation into the durable object of pleasurable and painstaking thought; Dryden offers the possibility that the megalith intended at once to kill and to entomb can be adjusted against the annihilator's desire into the cornerstone of unpredicted flourishing. The cyclops, passionately wishing ill, may be instrumental, like Goethe's Mephistopheles, in the furtherance of good: in a word, the damage that necessitates restoration may improve the original. As for Blake, he confessed, in 1809, his frustrated longing to fulfill a vast "national commission." He proposed a monument to Lord Nelson mastering Leviathan, in execution "as pure and as permanent as precious stones," standing no less than one hundred feet high. ${ }^{39}$ Was this the wish of a traitor? Not obviously. But the "Spiritual Form" of Nelson, unlike the celebrated admiral, is irenic - or pressing for mental rather than corporeal war. Blake envisages a new Nelson, as he envisaged a new Milton. The artist could foresee that there is no monument to end monuments, no interpretation to end interpretations; no final reckoning has numbered the stones of Stonehenge.

38. See Dryden, 445.

39. See Blake, ed. by Johnson and Grant, 425. 